\title{
(i)
}

\section{The Role of Institutional Quality in Trade-Growth Nexus: The Case of Emerging Economies}

\author{
${ }^{a}$ Muhammad Atiq-ur-Rehman, ${ }^{b}$ Hafeez-ur-Rehman, ${ }^{c}$ Fatima Farooq, ${ }^{d}$ Furrukh Bashir \\ ${ }^{a}$ Assistant Professor, Department of Economics, Higher Education Department, Punjab, Pakistan \\ Email: atiq164@live.com \\ ${ }^{\mathrm{b}}$ Chairman, School of Business Economics, University of Management and Technology, Lahore, Pakistan \\ Email: Hafeez.rehman@umt.edu.pk \\ ${ }^{c}$ Associate Professor, School of Economics, Bahauddin Zakariya University, Multan, Pakistan \\ Email: fatima@bzu.edu.pk \\ ${ }^{\mathrm{d}}$ Assistant Professor, School of Economics, Bahauddin Zakariya University, Multan, Pakistan \\ Email: furrukh@bzu.edu.pk
}

\begin{tabular}{|c|c|}
\hline ARTICLE DETAILS & ABSTRACT \\
\hline $\begin{array}{l}\text { History: } \\
\text { Accepted o7 March } 2021 \\
\text { Available Online March } 2021\end{array}$ & $\begin{array}{l}\text { This study aims at investigating the relationship between trade } \\
\text { openness and economic growth after incorporating the role of } \\
\text { institutions. Generalized method of moments (GMM) system technique } \\
\text { is applied by using data of } 17 \text { major emerging market economies (EMEs) }\end{array}$ \\
\hline $\begin{array}{l}\text { Keywords: } \\
\text { Trade Openness, Institutions, } \\
\text { Economic Growth, Dynamic } \\
\text { Panel data }\end{array}$ & $\begin{array}{l}\text { for the period 1995-2018. The empirical evidence suggests that trade } \\
\text { liberalization affects economic growth positively and significantly while } \\
\text { institutions play a supportive role in this regard. The interaction terms } \\
\text { are also generated to test the impact of the institutional environment on } \\
\text { the trade-growth relationship. The empirical results are robust to }\end{array}$ \\
\hline $\begin{array}{l}\text { JEL Classification: } \\
F_{15}, F_{130}, E 02, C_{23}\end{array}$ & $\begin{array}{l}\text { various specifications, confirming the positive role of institutions in } \\
\text { trade- growth nexus. The countries should develop a conducive } \\
\text { institutional and political environment to ensure the beneficial growth } \\
\text { effects of trade liberalization policy. }\end{array}$ \\
\hline
\end{tabular}

DOI: $10.47067 /$ ramss.v4i1.112

(C) 2021 The authors. Published by SPCRD Global Publishing. This is an open access article under the Creative Commons Attribution-Non

Commercial 4.0

Corresponding author's email address: fatima@bzu.edu.pk

\section{Introduction}

The impact of trade openness on economic growth is a matter of great concern for the policymakers in the era of globalization and economic liberalization. Does trade openness a causal effect on the economic growth of emerging economies? Do institutions play a vital role in promoting economic growth? Do trade openness and Institutions jointly affect economic growth positively? These are three important questions pertaining to trade-growth relation. The answer to the first two questions is clear to some extent. Trade openness does have a positive causal effect on economic growth (Dollar, 199; Frankel and Romer 1999; and Alesina et.al., 2000). The 
institutions play a favorable role in promoting growth (Acemoglu et. al. 2002; Johnson, 2005). The answer to the third question is somewhat crucial and debatable.

The emerging market economies have been engaged in trade liberalization reforms since the 1980 s to increase economic growth. Economic theory suggests that the trade liberalization reforms will make economies able to achieve higher growth rates by rising trade volumes. However, empirical literature about trade growth nexus has been mixed (Chaudhuri et al. 2008; Claustre et al. 2010). Some studies are good the trade liberalization will increase economic growth while others suggest that it will retard economic growth. Dollar and Kraay (2003) suggests that trade liberalization enhances the speed of income convergence. Easterly (2008) argues that trade openness causes income divergence rather than convergence in developing economies like Africa. According to Rodrik (2001), there is a systematic association between trade openness and economic growth. The countries get richer they dismantle restrictions in the way of trade.

The debate about the benefits of trade openness revolves around pro-trade and anti-trade groups. The pro-trade group advocates the gains from trade by specializing in the production of the good of comparative advantage. The exchange of the product after specialization will provide benefit to both trading partners. Moreover, the technological change and innovations are facilitated through the import of advanced technology which stimulates economic growth in the Emerging and developing economies (Edwards, 1991; Ahmed and Sattar, 2004). The anti-trade group is of the view that trade leads to the dumping of goods which adversely affects the developing countries. Free trade increase output and improved living standards but generate many winners and losers as the distributional consequences within states, raising fears about lower wages and job losses (Devadoss, 2006, Pavcnik, 2019).

The literature explains that the weakness of institutions is a major cause of the limited growth benefits of trade openness policy. After the seminal work of North (990) and Barro (1996), the debate about the role of institutional quality in promoting economic development has become a central element of economic policy. The sound institutional system works as a catalyst to promote economic growth (Easterly and Levine, 2003; Rodrik, et al., 2004). Some empirical studies suggest that the institutions are the primary condition for economic reforms in the developing economies (Acemoglu et al., 2003). A rich literature is available on the institutiongrowth nexus s available; however, the impact of institutions in the presence of outward-oriented trade policies has not been widely discussed. The objective of this paper is to empirically examine the impact of trade openness and institutions on the economic growth of major emerging economies.

\section{Literature Review}

According to economic theory, trade openness should stimulate output growth in the longrun by improving the efficiency of resource allocation. Trade liberalization also encourages technological development in the less advanced economies through hi-tech imports. The hitechnology imports are expected to enhance innovations, productivity and economic growth in the developing economies. However, the decades of trade liberalization experiences reveal mixed growth effects in developing countries (Dollar and Kraay 2003). Sachs and Warner (1995), and Alcala and Ciccone (2004) find a positive association between trade openness and economic growth. Dollar (1992) prepares an outward orientation index by incorporating exchange rate 
variability and trade distortions. He explores that the outward-oriented economies experience higher growth rates as compared to inward-oriented economies especially in the case of Asian developing nations. Sachs and Warner (1995) use trade openness and growth data for 89 developing economies for the years 1970 to 1989. Hall and Jones (1999) declare that the major cause of income differentials across nations is the difference in economic policies and institutions. The empirical results revealed that the globally integrated economies experience higher growth rates and outperform closed economies. However, the authors argue that trade volumes can also be determined by the own domestic policies of a country which can affect economic growth. The argument cast doubt on the conclusion that trade liberalization policy stimulates output growth. Frankel and Romar (1999) evaluate the influence of trade liberalization policy on growth after controlling for the endogeneity bias. They conclude that a one percent increase in openness to trade causes per capita income to rise by 0.5 percent or vice a versa. The authors elucidate that trade openness upsurges output growth through human and physical capital accumulation. Acemoglu et al. (2002) is considered Pioneer in developing a theoretical framework about the institutions-growth nexus. Acemoglu and Johnson (2005) empirical estimate the association between an institutional system and long-run economic growth. The authors use an instrumental variable approach for the estimation as they think that the institutional quality variable is endogenous to the country's income level. They find a positive and significant influence of property rights institutions on long-run economic growth.

Parallel literature is available on the contribution of institutional quality in the long-run economic growth. It is a growing consensus that the institutional system of a country plays a substantial role in the economic development of the countries. The supremacy of institutions and property rights protection facilitates the businesses and raise the level of the trader's confidence. One consensus reached in modern research is that institutions perform a pivotal role in making trade openness policy feasible for economic growth. A business-friendly institutional environment and cultural traits promote economic growth (Aghion et al., 2010). According to Rodriguez and Rodrik (2001), and Rodrik et al. (2004), better quality institutions perform an essential role in the growth effects of trade openness. The authors negate any independent effect of trade liberalization on economic performance. Dollar and Kraay (2003) tests the empirical results of Rodriguez and Rodrik (2001) and put forward opposite findings. They argue that it is challenging to examine the partial effects of openness and institutions on output growth. Trade liberalization plays a noteworthy role in supporting the growth process while institutions play only a negligible part. Alcala and Ciccone (2004) examine the partial effect of trade openness on productivity after controlling for the institutions. The authors find a positive and significant impact of real trade openness on productivity growth. They further declare that the real trade openness is the best measure to gauge the outward orientation of an economy due to differences in prices of non-tradable commodities between countries.

$\mathrm{Yu}$ (2010) considers a sample of 157 economies for the years 1962 to 1998 to conclude that more democratic countries with better intellectual property rights get good reputation which Surges their exports. Hadhek and Mrad (2015) estimate the relationship between trade openness institutions and growth in 23 OECD economies for the period 1990-2010. The empirical results using dynamic panel data estimation technique reveals that the institutional quality plays a decisive role in the association between trade liberalization and economic growth. Apkan and Atan (2016) use dynamic panel and pooled OLS approaches to estimate the influence of trade openness and institutions on economic growth in 23 economies of Sub-Saharan Africa. The study concludes that the positive growth effect of a liberalized trade policy is conditional on institutional quality. 
Silajdzic and Mehic (2018) explore the association between trade liberalization policy and growth in Central and Eastern Europe (CEE) countries using dynamic least square dummy variable (LSDV) and panel fixed effect estimation techniques. The empirical estimation reveals that the trade intensity measures have a positive association with economic growth while better institutions play a supportive role in the outward-oriented growth. Trade integration not only provides benefits through higher exports but also improves economic performance through hitech imports and technological innovations.

\section{Econometric Methodology and Data}

A general form of econometric relationship using panel data can be written as;

$$
Y_{i t}=\beta_{1} Y_{i, 1995}+\beta_{2} O_{P E N}+\beta_{3} X_{i t}+\beta_{4} I N S T_{i t}+u_{i t}
$$

Where $Y_{i t}$ is the dependent variable which is the growth rate of per capita real GDP. Initial GDP is denoted by $\mathrm{Y}_{\mathrm{i}, 1995}$ which is GDP per capita in the year 1995. Trade openness (OPEN) is expressed by using a common measure of exports plus imports as a percentage of GDP. Although there is no fully agreeable single measure of trade openness, however the general indicators for openness take into account the trade volumes which are important reflections of trade openness of an economy. Control variables are represented by $\mathrm{X}_{\mathrm{it}}$ involving years of schooling at the secondary level (Schooling), government expenditures as a percentage of GDP (Govt. expenditure) and total population (Population). Government expenditures are added in regression to capture the effect of government policies. The human capital is represented by average years of schooling at the secondary level. Population variable is also used in the model because a reasonable level of population of a country not only provides labor force but also helps in establishing markets.

The different specifications of the model are employed to check the robustness of the results. In the end, the interactions between trade openness and institutions are used to examine the joint effects of both variables on economic growth. The growth rate of per capita real GDP and the initial GDP are obtained from the World Development Indicators (WDI) database provided by the World Bank. The data on trade openness measures are obtained from the WDI. Two measures of openness are employed including merchandise trade (as a percentage of GDP). The data on control variables including years of secondary schooling $(\mathrm{SCH})$, government expenditures as a percentage of GDP (GOV) and total population (POP) are also obtained from WDI.

The data on institutional quality is obtained from the International Country Risk Guide (ICRG) by Political Risk Services (PRS) Group. The ICRG involves 22 variables in three subcategories naming political risk, financial risk, and economic risk. Political Risk is the main concern in the discussion about institutions. Political Rating contains 12 variables which cover political as well as social attributes. To represent institutional quality, we pick three common variables naming corruption, law and order and bureaucratic quality. Corruption reduces the efficiency of businesses and adversely affects governance. It causes a threat to foreign investors. Law and order signify the transparency and impartiality of a country's legal system. Bureaucratic quality symbolizes policy stability after any change in the government. Autonomous and better bureaucracy performs administrative functions without any political pressure. The sum of these three variables is used to represent institutions. Moreover, the fore mentioned three variables are also used separately in the regressions to obtain a detailed picture of the trade-growth nexus in a specific institutional environment. 
The role of institutions in strengthening the association between trade openness and economic growth is empirically examined for the seventeen major emerging market economies including Argentina, Brazil, Chile, China, Hungary, India, Indonesia, Malaysia, Mexico, Pakistan, Philippines, Poland, Russia, Thailand, Turkey, Ukraine, and Venezuela. A panel data sample for the period 1999-2018 is used for the empirical analysis. The data is transformed in 5-year averages to minimize the cyclical fluctuations. Generalized Method of Moments (GMM) seems to be a suitable method for estimation as it has the advantage of controlling the endogeneity of problem. We use modified and more sophisticated estimation technique namely system GMM introduced by Arellano and Bover (1995) and Blundell and Bond (1997). According to Bond et al. (2001), the system GMM has a feature of combining the previous set of equations in first differences with appropriately lagged levels as instrumental variables with additional equations set in the level form with proper lagged first differences as instrumental variables. The validity of instruments is evaluated by the Hansen test of over-identifying restrictions. The serial correlation problem is detected by using the Arellano \& Bond test for second-order serial correlation (ABm2). If GMM system estimates are not subject to second-order serial correlation then the validity of instruments is confirmed and the estimates ensure efficiency and consistency.

\section{Empirical Results and Discussion}

Table 1 shows the system GMM estimation pertaining to the relationship between trade openness, institutions and economic growth. It is revealed that the coefficient of initial income is negative and significant at one percent level confirming the convergence hypothesis. A significantly positive correlation is found between trade openness and GDP growth in all the six regressions. Trade openness coefficient ranges between 0.49 to 1.37 which shows that any a one percent increase in trade openness leads to raising GDP per capita by around 0.49 to 1.37 percent or vice a versa. Trade openness plays a pivotal role in stimulating economic growth by importing advanced technology and promoting specialization culture, mainly in the developing economies. By opening up the borders for trade, the emerging countries are able to share new technology and modern techniques of production.

The growth-promoting role of trade liberalization in EMEs can be observed in two ways. Firstly, the import liberalization facilitated the use of hi-tech machinery in production and technology is transferred to the region from the developed trading partners. Secondly, the export promotion policies give vent to innovations and competition. The population growth variable is positive and strongly significant at one percent level in all the six specifications. The population helps to form the domestic and global markets and also provides labor force to the different sectors of an economy. That's why our estimation results show that positive impact of population growth on economic growth. Government expenditure and schooling variables generally remain insignificant. The composite index namely institutions are statistically significant at one percent level. Institutions play a pivotal role in promoting economic growth through business efficiency and investors' confidence (Acemoglu et al., 2004; Rodrik, 2004). The sub-indices including corruption and law and order are also statistically significant at 3 percent and 1 percent level respectively while bureaucratic quality remains insignificant.

The countries with better scores in corruption or having lower levels of corruption experience more efficiency in businesses and achieve higher growth rates. Similarly, better law and order condition encourages investors and raise output growth. Bureaucratic quality is statistically insignificant because any change in the government leads to policy instability. So, the 
politically influenced bureaucracy dealing with instable policy remains unable to support economic growth in the developing countries. The insignificant p-values of Hansen test in all regressions indicate the validity of instruments.

Table 1: Dependent variable: Growth rate of real GDP per capita (Y)

\begin{tabular}{|c|c|c|c|c|c|c|}
\hline $\begin{array}{l}\text { System GMM } \\
\text { Regression }\end{array}$ & (1) & (2) & (3) & (4) & (5) & (6) \\
\hline Initial income & $\begin{array}{c}-0.3298 \\
(0.1192)^{*}\end{array}$ & $\begin{array}{c}-0.7402 \\
(0.1724)^{*}\end{array}$ & $\begin{array}{c}-0.9484 \\
(0.1817)^{*}\end{array}$ & $\begin{array}{c}-0.9669 \\
(0.1871)^{*}\end{array}$ & $\begin{array}{c}-0.7570 \\
(0.1830)^{\star}\end{array}$ & $\begin{array}{c}-0.9272 \\
(0.1842)^{*}\end{array}$ \\
\hline Openness & $\begin{array}{c}1.3658 \\
(0.2399)^{*}\end{array}$ & $\begin{array}{c}0.8323 \\
(0.2645)^{*}\end{array}$ & $\begin{array}{c}0.6289 \\
(0.2824)^{* *}\end{array}$ & $\begin{array}{c}0.8284 \\
(0.2752)^{*}\end{array}$ & $\begin{array}{c}0.4928 \\
(0.2838)^{* * *}\end{array}$ & $\begin{array}{c}0.7975 \\
(0.2813)^{*}\end{array}$ \\
\hline Schooling & & $\begin{array}{l}-1.2085 \\
(1.1713) \\
\end{array}$ & $\begin{array}{l}-2.0412 \\
(1.2282) \\
\end{array}$ & $\begin{array}{l}-1.5493 \\
(1.2231) \\
\end{array}$ & $\begin{array}{c}-2.4981 \\
(1.2308)^{\star *}\end{array}$ & $\begin{array}{l}-1.3333 \\
(1.2104) \\
\end{array}$ \\
\hline Population & & $\begin{array}{c}0.4322 \\
(0.0833)^{*}\end{array}$ & $\begin{array}{c}0.4259 \\
(0.0867)^{*}\end{array}$ & $\begin{array}{c}0.4240 \\
(0.0877)^{*}\end{array}$ & $\begin{array}{c}0.4386 \\
(0.0866)^{*}\end{array}$ & $\begin{array}{c}0.3961 \\
(0.0868)^{*}\end{array}$ \\
\hline Govt. Expenditure & & $\begin{array}{l}-0.0085 \\
(0.6765)\end{array}$ & $\begin{array}{c}0.7552 \\
(0.7099)\end{array}$ & $\begin{array}{c}0.7463 \\
(0.7119)\end{array}$ & $\begin{array}{c}0.3846 \\
(0.7116)\end{array}$ & $\begin{array}{c}0.8101 \\
(0.7185)\end{array}$ \\
\hline Institutions & & & $\begin{array}{c}0.2747 \\
(0.0823)^{*}\end{array}$ & & & \\
\hline Corruption & & & & $\begin{array}{c}0.3179 \\
(0.2023)^{* * *}\end{array}$ & & \\
\hline Law \& order & & & & & $\begin{array}{c}0.8032 \\
(0.1682)^{*}\end{array}$ & \\
\hline $\begin{array}{l}\text { Bureaucratic } \\
\text { quality }\end{array}$ & & & & & & $\begin{array}{c}0.2260 \\
(0.2259)\end{array}$ \\
\hline Hansen (P-value) & 1.000 & 1.000 & 1.000 & 1.000 & 1.000 & 1.000 \\
\hline Observations & 404 & 404 & 385 & 385 & 385 & 385 \\
\hline Countries & 17 & 17 & 17 & 17 & 17 & 17 \\
\hline
\end{tabular}

Note: The annual data for the period 1995-2018 is used. All variables are in $\log$ form except INST. Estimates are obtained by applying one-step system GMM dynamic panel estimator of Arellano and Bond (1991). The standard errors are given in parentheses where *, $* *$ and $* * *$ indicate significance at $1 \%, 5 \%$ and $10 \%$ levels of significance respectively.

Table 2 presents the effect of interactions between trade openness and institutions on GDP growth per capita. The interactions between trade openness and institutional quality measures are used to examine their partial growth effects. The coefficient of initial income is negative and significant at one percent level which indicates the income convergence. A significantly positive correlation is found between population and GDP per capita growth in all the six regressions. Schooling variable is weakly significant with a negative sign in just two specifications while government expenditure variable remains insignificant throughout.

The population growth variable is positive and strongly significant at one percent level in all the six specifications. The population helps to form the domestic and global markets and also provides labor force to the different sectors of an economy. It shows the growth effect of interactions between trade openness and institutions. The empirical results reveal that all the interactions between trade openness and institutional quality measures are statistically significant with positive coefficients. The results are in line with Thennakoon and Dissanayake (2015) and Hadhek and Mrad (2015). The composite index of institutions is positive and statistically significant at 5 percent level which shows that the better institutional quality supports the trade 
openness policy to boost up economic growth. The interactions of openness with corruption and law and order are both statistically significant at 5 percent level. The minimum level of corruption enhances the confidence investors and supports the government's outward-oriented trade policy to stimulate economic growth.

Law and order is the most imperative condition for the better economic performance because the impartiality of a legal system, transparent property rights and protection of businesses flourish an economy by reaping the benefits of trade liberalization policy. The bureaucratic quality interacted with trade openness policy is statistically significant. It implies that if a consistent trade openness policy environment is provided for the functioning of bureaucracy then economic growth upsurges. The p-value of the Hansen test is insignificant in each regression which confirms the validity of instruments.

Table 2: Dependent variable: Growth rate of real GDP per capita (Y)

\begin{tabular}{|c|c|c|c|c|}
\hline System GMM Regression & (1) & (2) & (3) & (4) \\
\hline Initial income & $\begin{array}{c}-0.6685 \\
(0.2198)^{*}\end{array}$ & $\begin{array}{c}-0.7196 \\
(0.2216)^{*}\end{array}$ & $\begin{array}{c}-0.4920 \\
(0.2190)^{* *}\end{array}$ & $\begin{array}{c}-0.7653 \\
(0.2053)^{*}\end{array}$ \\
\hline Openness & $\begin{array}{l}-1.5089 \\
(0.9921) \\
\end{array}$ & $\begin{array}{l}-0.8993 \\
(0.8737) \\
\end{array}$ & $\begin{array}{c}-1.3136 \\
(0.8622) \\
\end{array}$ & $\begin{array}{c}-0.6377 \\
(0.8486) \\
\end{array}$ \\
\hline Schooling & $\begin{array}{c}-2.2021 \\
(1.2333)^{* * *}\end{array}$ & $\begin{array}{l}-1.7499 \\
(1.2269)\end{array}$ & $\begin{array}{c}-2.8820 \\
(1.2465) * *\end{array}$ & $\begin{array}{l}-1.2204 \\
(1.2136) \\
\end{array}$ \\
\hline Population & $\begin{array}{c}0.7783 \\
(0.1793)^{*}\end{array}$ & $\begin{array}{c}0.6991 \\
(0.1585)^{*}\end{array}$ & $\begin{array}{c}0.7599 \\
(0.1688)^{*}\end{array}$ & $\begin{array}{c}0.6165 \\
(0.1505)^{*}\end{array}$ \\
\hline Govt. expenditure & $\begin{array}{l}0.7757 \\
(0.7114) \\
\end{array}$ & $\begin{array}{l}0.8635 \\
(0.7141) \\
\end{array}$ & $\begin{array}{c}0.2115 \\
(0.7180) \\
\end{array}$ & $\begin{array}{c}0.9274 \\
(0.7224) \\
\end{array}$ \\
\hline Institutions & $\begin{array}{c}-0.9123 \\
(0.5340)^{* * *}\end{array}$ & & & \\
\hline Openness* Institutions & $\begin{array}{c}0.2948 \\
(0.1311)^{* *}\end{array}$ & & & \\
\hline Corruption & & $\begin{array}{c}-2.8956 \\
(1.5550)^{\star \star *}\end{array}$ & & \\
\hline Openness ${ }^{*}$ Corruption & & $\begin{array}{c}0.7875 \\
(0.3779)^{* *}\end{array}$ & & \\
\hline Law \& order & & & $\begin{array}{l}-1.5916 \\
(1.0923)\end{array}$ & \\
\hline Openness* Law \& order & & & $\begin{array}{c}0.6133 \\
(0.2763)^{* *}\end{array}$ & \\
\hline Bureaucratic quality & & & & $\begin{array}{l}-2.5529 \\
(1.5662)\end{array}$ \\
\hline $\begin{array}{l}\text { Openness* } \\
\text { Bureaucratic quality }\end{array}$ & & & & $\begin{array}{c}0.6739 \\
(0.3758) * * *\end{array}$ \\
\hline Hansen (P-value) & 1.000 & 1.000 & 1.000 & 1.000 \\
\hline Observations & 385 & 385 & 385 & 386 \\
\hline Countries & 17 & 17 & 17 & 17 \\
\hline
\end{tabular}

Note: The annual data for the period 1995-2018 is used. All variables are in log form except INST. Estimates are obtained by applying one-step system GMM dynamic panel estimator of Arellano and Bond (1991). The standard errors are given in parentheses where *, ** and $* * *$ indicate significance at $1 \%, 5 \%$ and $10 \%$ levels of significance respectively.

\section{Conclusion}


The modern research postulates that the trade openness policy supported with suitable institutional structure encourages economic growth while the limited growth effects of openness policy are observed due to fragile institutions. The working hypothesis is formulated that the better institutions are necessary if an economy is to reap the full growth benefits of trade liberalization policy. In light of the aforementioned hypothesis, this study examines the relationship between trade openness, institutions and economic growth in the emerging economies. A system GMM estimation technique is applied for the sample of 17 EMEs from 1995 to 2018. Empirical estimates indicate that trade openness and institutions influence economic growth positively and significantly. Trade

openness plays a pivotal role in stimulating economic growth by importing advanced technology and promoting specialization culture, mainly in the developing economies. By opening up the borders for trade, the emerging countries are able to share new technology and modern techniques of production. Institutions play a fundamental role in raising economic growth by enhancing business efficiency and investors' confidence. The interaction terms are also generated to test the impact of the institutional environment on the trade-growth relationship. The empirical results are robust to various specifications, endorsing the positive role of institutions in trade- growth relationship. The policies should be designed to improve institutional quality in the wake of globalization and trade liberalization. The control of corruption and better law and order situation can attract investors and exporters. The countries should develop an auspicious institutional and political environment to ensure the beneficial growth effects of trade liberalization policy.

\section{References}

Acemoglu D., S. Johnson and J. Robinson (2004). Institutions as fundamental cause of long-run growth, Handbook of Economic Growth edited by Philippe Aghion and Steve Durlauf.

Acemoglu, D., S. Johnson, and J. Robinson (2005). Institutions as a fundamental cause of long-run growth, in Aghion, P. and S. Durlauf (eds), Handbook of Economic Growth.

Acemoglu, D. and J. Robinson (2008). The role of institutions”, Commission on Growth and Development Working Paper, No.10, pp. 10-28.

Aghion, P., Y. Algan, P. Cahuc and A. Shleifer (2010). Regulation and distrust. Quarterly Journal of Economics, Vol. 125, No. 3, pp. 1015-1049.

Aghion, P., Howitt, P. and F. Murtin (2011). The relationship between health and growth. Review of Economics and Institutions, Vol. 2, No. 1, pp. 1-24.

Ahmed, S. and Z. Sattar, (2004). Impact of trade liberalization: looking at the evidence. Economic and Political Weekly, pp. 4059-4067.

Akpan, U. F., \& Atan, J. A. (2016). Relationship between trade openness, institutions and economic growth in Sub-Saharan Africa: a further look at the evidence. Journal of Economics, Management and Trade, 1-20.

Alege, P. O. (1993). Export and growth in the Nigerian economy: a causality test. The Indian Journal of Economics, Vol. XXIII, Part III No. 290, January.

Arellano, M., \& Bond, S. (1991). Some tests of specification for panel data: Monte Carlo evidence and an application to employment equations. Review of Economic Studies, 58, 277-297.

Arellano, M., \& Bover, O. (1995). Another look at the instrumental variable estimation of errorcomponents models. Journal of Econometrics, 68(1), 29-51.

Baliamoune-Lutz, M. and L. Ndikumana (2007). The growth effects of openness to trade and the role of institutions: new evidence from African countries. Economics Department Working 
Paper Series, Paper 38, University of Massachusetts, Amherst, USA.

Chaudhuri, S., S. Yabuuchi and U. Mukhopadhayay, (2006). Inflow of foreign capital and trade liberalization in a model with an informal sector and urban unemployment. Pacific Economic Review, 11(1), pp. 87-103.

Claustre, B.M., J.K. Timoh and J.R. Kim (2008). Trade liberalization, growth and productivity. Paper presented at the Conference titled 'New directions in International Trade Theory'at the University of Nottingham.

Djankov, S., R. LaPorta, F. López de Silanes, and A. Shleifer (2003). Courts. Quarterly Journal of Economics, Vol. 118, No. 2, pp. 453-517.

Dollar, D. and A. Kraay (2003). Institutions, trade and growth. Journal of Monetary Economics, Vol.50, pp. 133-162.

Easterly, W. (2008). Design and reform of institutions in LDCs and transition economies institutions: top down or bottom up? American Economic Review, Vol.98, No.2, pp.95-99.

Easterly, W. and R. Levine (2003). Africa's growth tragedy: policies and ethnic divisions. Quarterly Journal of Economics, Vol.112, No.4, pp.1203-50.

Easterly, W. and S. Rebelo (1993). Fiscal policy and economic growth. Journal of Monetary Economics Vol. 32, pp. 417-458.

Eriș, M. N., \& Ulașan, B. (2013). Trade openness and economic growth: Bayesian model averaging estimate of cross-country growth regressions. Economic Modelling, 33, 867-883.

Frankel, J.A. and D. Romer (1999). Does trade cause growth? The American Economic Review, Vol. 89, No. 3, pp. 379-399.

Gries, T., \& Redlin, M. (2012, June). Trade openness and economic growth: a panel causality analysis. In International conferences of RCIE, KIET, and APEA, March (pp. 16-18).

Hadhek, Z., \& Mrad, F. (2015). Trade openness, institutions and economic growth. European Journal of Economics, Finance and Administrative Sciences, 75, 96-104.

King, R. and R. Levine (1993). Finance and growth: Schumpeter might be right. Quarterly Journal of Economics, Vol. 108, No.3, pp. 717-738.

Matthew, O., \& Adegboye, F. B. (2014). Trade openness, institutions and economic growth in subSaharan Africa (SSA). Developing Country Studies, 4(8), 18-30.

Rodrik, D. (2001). The global governance of trade as if development really mattered. Trade and Human Development Series, UNDP, New York.

Rodrik, D., A. Subramanian and F. Trebbi (2004). Institutions rule: the primacy of institutions over geography and integration in economic development. Journal of Development Economics, Vol.78, No.2, pp. 529-547.

Stensnes, K. (2006). Trade openness and economic growth: do institutions matter?. Norwegian Institute of International Affairs, paper no. 702.

Tavares, J. and R. Wacziarg (2001). How democracy affects growth. European Economic Review, Vol.45, No. 8, pp. 1341-1379.

Thennakoon, J., \& Dissanayake, J. (2015). Trade openness, income, and role of institutions: A revisit using heterogeneous panel data models. Cogent Economics \& Finance, 3(1), 1020031.

Wacziarg, R. and K. Welch (2008). Trade liberalization and growth: new evidence. World Bank Economic Review

Yu, M. (2010). Trade, democracy, and the gravity equation. Journal of Development Economics, 91(2), 289-300. 